\title{
ФОРМУВАННЯ ОСОБИСТОСТІ ТА МОТИВАЦІЇ ДО НАВЧАННЯ У СТУДЕНТІВ МЕДИЧНОГО УНІВЕРСИТЕТУ
}

\author{
К. В. Півторак, І. В. Феджага
}

Вінницький національний медичний університет імені М. І. Пирогова

\section{FORMING OF PERSONALITY AND MOTIVATION TO STUDY IN THE STUDENTS OF MEDICAL UNIVERSITY}

\author{
K. V. Pivtorak, I. V. Fedzhaha
}

Vinnytsia National Medical University by M. I. Pyrohov

\begin{abstract}
У статті розглядається сучасний стан проблеми формування мотивації до навчання та особистості студентів на кафедрах клінічної фармації та клінічної фармакології, внутрішньої та сімейної медицини.
\end{abstract}

This article adduces the current status of the forming of motivation for learning and students' personality in the departments of clinical pharmacy and clinical pharmacology, internal and family medicine.

Вступ. Сучасна медицина високих технологій висуває особливі вимоги до системи навчання. Навчальний процес як складова частина загального процесу виховання всебічно розвиненої особистості, що відповідає потребам сучасного суспільства, повинен забезпечити виконання цього завдання реалізацією трьох функцій: освітньої, розвиваючої та виховної.

Нині перед вищою школою стоїть дилема: або “штампування" функціонерів, або формування розвиненої особистості. Від вибору у цій ситуації залежить місце і місія вищої освіти в сучасному суспільстві: в першому випадку вища освіта плентається позаду суспільства, у другому - забезпечує його розвиток. Цей вибір і визначає спрямованість реформи вищої школи [1].

Становлення особистості професіонала визначається формуванням складних психічних систем регуляції діяльності та формуванням особливостей поведінки. Кожна професія впливає на розвиток схожих рис особистості, іï установок, мотиваційної сфери та відповідної системи цінностей. У своєму розвитку особистість засвоює основні особливості професії, i ці характеристики починають проявлятися в інших сферах життєдіяльності. Це притаманно тим особам, що зацікавлені професійною діяльністю, відчувають задоволення від іiі освоєння та практичної роботи. Іншими словами, такі фахівці характеризуються високим рівнем ідентифікації зі своєю професією [2].

Посилення інтересу до проблеми мотивації студентів до навчання як рушійної сили в процесі їх на- вчання у вузі пов'язане з пошуком факторів впливу на особистість, з виявленням динамічних, енергетичних і смислоутворюючих закономірностей співвідношення між ііі активізуючими і змістовними детермінантами [3].

Проблема створення педагогічних умов для мотиваційного поля студентів $є$ актуальною, оскільки висвітлює необхідність нових підходів до організації навчально-виховного процесу у вищій освіті, перегляду існуючих методів, форм і засобів навчання у медичному вузі, використання основних положень особистісно орієнтованого підходу у процесі викладання.

Основна частина. Мета роботи: теоретично охарактеризувати процес формування мотивації до навчання та кращих рис особистості лікаря, розробити шляхи удосконалення цього процесу. Виходячи з мети роботи, ми поставили завдання проаналізувати досвід формування мотивів у навчальному процесі медичного університету та розробити методичні рекомендації щодо формування позитивних мотивів навчання, що сприяють особистісному зростанню майбутніх лікарів.

У психології і педагогіщі напрацьовано багато ідей, що стосуються організації професійного навчання у вищій школі.

Ще в 1856 році М. І. Пирогов у статті “Вопросы жизни" різко виступив проти школи для різних верств населення та ранньої утилітарно-професійної виучки, яку прагнув ввести царський уряд за рахунок зниження рівня загальної освіти молоді. Він протиста-

(C) К. В. Півторак, І. В. Феджага 
вив офіційному курсу освіти ідею загальнолюдського виховання, яка повинна підготувати до громадського життя високоморальну людину з широким розумовим кругозором [4].

Розмірковуючи про методологічні засади вузівської підготовки практичного психолога, Н. Л. Коломінський висловлює думку, що основними функціями вузівського навчання, спрямованими на професійне становлення особистості, є такі: формування професійних (цільових, смислових, операційних) установок, формування системи професійно важливих знань, науково-культурного кругозору; формування професійно важливих умінь, навичок; виявлення, розвиток професійно важливих здібностей (інтелектуальних, перцептивних, комунікативних, експресивних, організаторських, мовних та ін.); розвиток духовних потреб майбутнього спеціаліста, морально-етичне вдосконалення його особистості; сприяння самоактуалізації кожної особистості, культивування розвитку індивідуальності, як передумова індивідуального стилю праці [5].

Як і будь-який інший вид, мотивація до навчання в медичному вузі визначається цілим рядом специфічних для цієї діяльності факторів. По-перше, вона визначається самою освітньою системою, освітньою установою, де здійснюється навчальна діяльність, подруге, організацією освітнього процесу, по-третє, суб' єктними особливостями того, хто навчається (вік, стать, інтелектуальний розвиток, здібності, рівень вимог, самооцінка, взаємодія з іншими студентами і т. д.), по-четверте, суб'єктними особливостями педагога i, перш за все, системою відношення його до студента, до справи, по-п'яте, специфікою навчального предмета [6].

Нами проаналізовано навчання студентів на кафедрах клінічної фармації та клінічної фармакології, внутрішньої та сімейної медицини у вирішенні практичних задач діагностики та лікування хворих, подальшого формування клінічного мислення, лікарської професійної поведінки, яка базується на деонтологічних засадах.

Особливості кафедри клінічної фармації та клінічної фармакології в тому, що предмет є базовим для формування майбутнього лікаря, дає необхідний алгоритм застосування набутих теоретичних знань, навичок та вмінь в наступній клінічній діяльності, сприяє подальшому формуванню клінічного мислення, лікарської професійної поведінки, яка базується на деонтологічних засадах. Потужним фактором, що сприяє оптимізації навчального процесу, є логіка та глибоке розуміння клінічного значення теоретичного матеріалу, який розглядається на практичному занятті. Гармонійне поєднання навчальної діяльності на практичних заняттях досягається шляхом надання заняттям проблемного характеру. Останнім часом успішно впроваджено в навчальний процес розв'язання ситуаційних задач за темою заняття, розгляд задач із бази даних ліцензійного інтегрованого іспиту “КРОК-2". Створення дискусії навколо цих питань сприяє формуванню клінічного мислення студентів.

Впровадження нової методології навчання (кредитно-модульної системи) вносить деякий дисонанс в уяву про класичне навчання в медичному вузі. Акценти та переваги в розподілі педагогічного часу під час заняття були направлені саме на пацієнта, контакти $з$ ним, елементи деонтології впроваджувалися на практиці, що сприяло формуванню у студентів розуміння важливості таких контактів та практичних навичок, сприяло формуванню уміння індивідуального підходу до хворого, без якого неможлива реалізація оптимальної фармакотерапії.

Викладання на кафедрі клінічної фармації і клінічної фармакології студентам 5-го курсу медичного факультету дисципліни "Клінічна фармакологія" має важливе значення, з урахуванням міждисциплінарних аспектів цього предмета, знання якого потрібне лікарям будь-якої спеціалізації. На жаль, розуміння цього факту при формуванні програм у вузах (як для студентів, так і для інтернів) недостатнє, підтвердженням чого є мінімальна кількість годин при навчанні в медуніверситеті проти аналогічної ситуації в країнах Свропи [7] та фармацевтичних факультетів, де обсяг навчання з фармакології на порядок більше. Тематика практичних занять (при відсутності лекцій) обмежується найбільш важливими групами препаратів, що застосовуються при поширених захворюваннях. Одне практичне заняття вимагає підготовки 3 декількох груп лікарських засобів, що інколи не відповідає можливостям студента. Тому на курацію хворих відведено лише 2 години позааудиторного часу, що знижує значення цієї складової навчання.

Наш досвід викладання клінічної фармакології студентам-лікувальникам за кредитно-модульною системою свідчить, що така система має як позитивні, так і негативні риси [8]. До перших слід віднести збільшення мотивації у студентів до засвоєння теми, щоб отримати більшу кількість балів. Тим більше, що опитування проводиться на кожному занятті. Але ця мотивація має свої особливості - вона обернена переважно на теоретичні знання, і не має спрямованості на практичну орієнтацію. Тим більше, що обмежена кількість годин не дозволяє наблизити студентів до ліжка хворого і отримати їм власний досвід ефективності та безпеки фармакотерапії. 
Успішність проблемного навчання забезпечується спільними зусиллями викладача і студентів. На кафедрі внутрішньої та сімейної медицини досить ефективним $€$ клінічний семінар, який має творчий та дослідницький характер, коли в ході обстеження хворого поновлюються або набуваються знання пропедевтики внутрішніх хвороб, клінічної інтерпретації симптомів внутрішніх хвороб, патофізіологічне обгрунтування симптомів хвороби, використання параклінічних методів обстеження в структурі діагностичного алгоритму та вироблення правильного тактичного та лікувального підходу до хворої людини. Основною методичною особливістю клінічного розбору хворого $€$ активна участь всіх присутніх. В ході обговорення випадку в учасників виникає бажання поділитися своїми думками, досвідом, знаннями, виказати свої сумніви, підтримати та повніше аргументувати думки. Відштовхуючись від інформації про конкретного хворого, можна підвести учасників до поглибленого обговорення питань етіології, патогенезу, морфології, диференційної діагностики, лікування та профілактики визначеного захворювання. Слід підкреслити, що предмет дискусії під час розбору не $є$ надуманим чи нав'язаним, він визначається ходом обговорення конкретного хворого. Це підтверджує нерозривний зв'язок теоретичних питань 3 повсякденною клінічною практикою, оскільки таке ж коло питань, асоціацій, логічних побудов повинно виникати у лікаря в його повсякденній роботі. Навчання студентів на кафедрі під час клінічних розборів хворих направлене не тільки на розвиток професійних, алей особистих якостейлікаря, адже він не тільки лікар, але й психолог, педагог, коли раціональна діяльність поєднується і збагачується емоційною. Зосередженість уваги, терпіння, проникливість, культура спілкування з людьми, мистецтво спілкування - невід'ємні риси, які відносяться до професійних якостей лікаря і формуються під час навчального процесу під впливом всього колективу кафедри при особливій ролі викладача як терапевта-професіонала та особистості.

До негативних явищ процесу навчання слід віднести посилення акценту на тестовому контролі. Значна частка часу витрачається на вирішення тестів, але студенти намагаються вивчити правильні відповіді, інколи вгадують відповідь. Розуміння та обгрунтування відповідей на ці ж питання при усному опитуванні викликає значні труднощі і підтверджує дефіцит клінічного мислення, яке втрачено за рахунок відсутності навчання коло ліжка хворого. Слід відмітити такі негативні аспекти, коли студенти намагаються шукати допоміжні заходи для вирішення тестів - обмін інформацією між собою, “допомога” мобільних теле- фонів тощо. Зрозуміло, що такі ситуації аж ніяк не сприяють формуванню порядної особистості, а націлюють студента на вирішення поставлених завдань будь-яким, в т. ч. некоректним шляхом.

Проявити себе, як справжній лікар, кожен студент може на курації хворого, коли потрібно застосувати набуті теоретичні знання на практиці.

Відсутність або ж бідність клінічного мислення також спостерігається при захисті Протоколів ефективності та безпеки застосування лікарських засобів, під час курації хворих. Студенти вважають, що для захисту протоколу курації достатньо його тексту, в якому висвітлені питання діагностики, характеристики фармакодинаміки та фармакокінетики препаратів, показань, протипоказань до призначення ліків, взаємодія між ними. Оскільки студенти не володіють тонким розумінням диференційованого підходу до призначення фармакотерапії, то вони і не спроможні чітко та впевнено пропонувати альтернативне лікування, тобто найбільш оптимальне, у разі неефективності чи недотримання стандартів та формулярів терапії лікарями.

Найбільш складним для відповідей $є$ питання негативної взаємодії лікарських засобів між собою, елементи поліпрагмазії, які не помічаються студентами при оцінці фармакотерапії хворого. Одна із складових такого нерозуміння - неадекватна довіра до дії лікаря, студенти не наважуються помітити очевидні помилки (які і в світі, за даними наукових досліджень, достатньо часто зустрічаються), у них відсутня сміливість пропонувати інші варіанти терапії. Тобто таке навчання не стимулює до розкриття широти поглядів, елементів фантазії, дискусії, вирішення проблеми з власного погляду. Студенти інколи не вміють висловлювати або відстоювати свої думки.

На вирішення ситуаційних завдань теж витрачається багато часу, що обумовлено повільним темпом мислення студентів, а через велике інформаційне перевантаження заняття страждає детальне обговорення найбільш важливих характеристик груп препаратів, їх взаємодії, особливостей застосування в окремих ситуаціях (залежно від віку хворих, статі, супутньої патології тощо).

Щодо інших складових кредитно-модульної системи, то позитивним можна вважати додаткові бали за індивідуальну роботу студентів, що спонукає їх до участі у студентських гуртках та конференціях, реферуванні додаткового поглибленого матеріалу для практичних занять. Але це стосується значно обмеженого контингенту студентів - одна - три особи в групі. В цілому, в боротьбі за бали змінюється об'- 
єктивність самооцінки студентів, на тлі збільшення власних амбіцій, вони вважають себе білыш досвідченими та навченими, ніж є насправді. Це викликає протиріччя між належним етичним ставленням до навчання, а саме між метою накопичення професійних вмінь, яка втрачається, та їх обмеженим і вузьким способом досягнення - лише боротьбою за оцінку. Все це обумовлено умовами навчання в Україні, які не відповідають вимогам та рекомендаціям кредитно-модульної системи, а саме - необхідність наявності в групі лише декількох студентів (тоді збільшувалися б індивідуальні контакти з викладачем, можливості індивідуального контролю освоєння знань та практичних навичок). Перевантаження груп кількістю до 10-12 студентів, зрозуміло, не може забезпечити належний психологічний клімат у групах, наслідком чого є відсутність оптимальних етичних умов для розвитку особистості [9].

Таким чином, постійне прагнення викладача вищої медичної школи до поліпшення якості навчання, через розвиток свого творчого потенціалу дозволить забезпечувати мотивацію навчання студентів, конкурентоспроможність вузу, гарантії високої якості його випускників. Поєднання різноманітних прийомів оволодіння професійними навичками, створення сприятливої атмосфери для розвитку клінічного мислення дає можливість сформувати особистість лікаря-спеціаліста високого гатунку.

Висновки: 1. Особистість лікаря має бути головним і вирішальним фактором клінічної медицини.

\section{Література}

1. Бех І. Д. Виховання сучасної вузівської молоді / І. Д. Бех // Філософія освіти XXI століття : проблеми і перспективи : зб. наук. праць.-К., 2000. - Вип. 3. - С. 229-232.

2. Тадіян С. В. Проблеми формування професійної свідомості фахівця ДПО в умовах ВНЗ/ С. В. Тадіян // Формування та розвиток особистості в умовах вищих навчальних закладів МНС України : матеріали Першої міжвузівської науково-практичної конференції, 19 грудня 2003 року. - Харків, 2003.

3. Запорожан В. М. Взаємозв'язок мотивації досягнень та успіхів у навчанні у студентів медичного факультету / В. М. Запорожан, Л. Р. Нікогосян, К. В. Аймедов // Медична освіта. - 2011. - № 2. - С. 108-113.

4. Константинов Н. А. История педагогики / Н. А. Константинов, Е. Н. Медынский, М. Ф. Шабаева.-М. : Просвещение, 1982.-С. 201.

5. Коломінський Н. Л. Методологічні засади професійної підготовки практичного психолога / Н. Л. Коломінський // Практична психологія та соціальна робота. - 2003. №4. - С. 12-13.

6. Результати впровадження нових технологій навчання
2. Головними детермінантами особистісного зростання майбутнього професіонала у медичному університеті є: концептуальна єдність і наступність змісту, форм і методів навчання; проблемно-орієнтований, розвивальний характер викладання, зв'язок між теорією та практикою; відкритість освітнього процесу і змісту навчального матеріалу до інновацій; індивідуалізація та диференціація навчального процесу; співробітництво викладачів зі студентами в навчальному процесі.

3. Клінічний семінар - клінічний розбір випадку хвороби в амбулаторного хворого є високоефективною формою навчання студентів, при якій активна пізнавальна діяльність стимулюється життєвою проблемною ситуацією - наявністю хворого, який потребує негайного вирішення проблеми діагностики його захворювання та ефективного лікування.

4. Колективна, за участю співробітників кафедри, робота під час клінічних розборів пацієнтів сприяє формуванню необхідних морально-етичних рис та деонтологічних норм поведінки майбутніх лікарів-професіоналів.

5. У вищій медичній школі проблема комплектування навчальних груп стоїть найбілыш гостро. Тільки в найменшому складі академічної групи (не більше 5 осіб) можливе вироблення практичних навичок івмінь лікаря.

6. Задоволення від самого процесу навчання є вагомим, постійно діючим джерелом мотивації до навчання, що називають радістю пізнання. Викладач повинен захопити студента предметом, привернути його до самостійної роботи, зацікавити в результатах.

за кредитно-модульною системою у Вінницькому національному медичному університеті / В. М. Мороз, Т. Л. Полеся, Ю. Й. Гумінський, Л. В. Фоміна // Медична освіта. -2011.-№ 2. -C. 83-85.

7. Кліщ Г. І. Реформування медичної освіти в Австрії : зразок успішного проведення і приклад для наслідування / Г. І. Кліщ // Медична освіта. - 2011. - № 1. - С. 58-66.

8. Особливості впливу кредитно-модульної системи на формування мотивації та особистості студентів-медиків / О. О. Яковлева, Н. В. Коновалова, І. О. Дорошкевич [та ін.] // Актуальні проблеми формування особистості лікаря у студентів-медиків : матеріали Х ювілейної міжнародної науково-практичної конференції (Київ, 25 березня 2010 року). -К.: СПД “Рудак”, 2010.-С. 140-141.

9. Яковлева О. О. Соціально-економічні передумови формування особистості спеціалістів у медицині / О. О. Яковлева, К. В. Півторак, Л. А. Вознюк // Актуальні проблеми формування особистості лікаря у студентів-медиків : матеріали XI міжнародної науково-практичної конференції (Київ, 23 березня 2011 року). -К., 2011.-С. 124. 